\title{
What are the factors that an opportunity sample of UK students insinuate as being associated with their wastage of food in the home setting?
}

\author{
by Clark, J. and Manning, L.
}

Copyright, Publisher and Additional Information: This is the author accepted manuscript. The final published version (version of record) is available online via Elsevier

Please refer to any applicable terms of use of the publisher.

DOI: https://doi.org/10.1016/j.resconrec.2017.11.005

$\mathbf{H}$ 


\section{What are the factors that an opportunity sample of UK students insinuate as being} associated with their wastage of food in the home setting?

\section{Jessica Clark and Louise Manning ${ }^{1}$ \\ Department of Food Science and Agri-food Supply Chains}

Harper Adams University, Newport, Shropshire, TF10 8NB

(1) corresponding author Imanning@harper-adams.ac.uk

\section{Abstract}

The aim of this research was to investigate the factors that influence student awareness and behaviour associated with food waste. The study is exploratory in nature and the qualitative research approach contextualises personal accounts of food waste awareness and behaviour. Semi-structured interviews were undertaken with students $(\mathrm{n}=50)$ from 12 households, who were enrolled at a UK university. Qualitative data was collected and thematically analysed using Microsoft NVivo 11 and a thematic map developed to firstly postulate how students' awareness and behaviour associated with food waste is influenced and secondly to support further study in this area. In order to tackle the issue of students' food waste, measures to increase awareness of food waste and improving design of kitchen environments should be adopted. However the latter is often not possible in short-term rented accommodation. The research contributes to the existing area of research and provides additional evidence for the factors that influence students' food waste behaviour.

Keywords: food, waste, consequences, awareness, student, resources, behaviour

\section{Highlights}

- Fifty students interviewed in twelve households about their food waste practice.

- Multiple factors of influence including: habits, awareness, and social influences.

- Measures to increase awareness and improve kitchen design should be adopted.

\section{Introduction}

Global food waste is estimated to be 1.6 billion tonnes annually of which 1.3 billion tonnes is edible with a value of $\$ 750$ billion (FAO, 2017). This scale of food waste impacts society, the environment and the wider economy, in a world that is already struggling to feed 
the population. Global food production will need to increase by $50-70 \%$ to feed the 9.3 billion people living on the planet by 2050 , whilst natural resources are becoming ever more scarce (Bond et al. 2013). Consequently, food supply chains need to become more sustainable from farm to fork, including by reducing existing levels of personal food waste. Food safety scares too can also have a major impact on supply chain food waste: for example, a Salmonella warning caused 32\% of American tomatoes to be unharvested in 2008 (Gunders, 2012).

Total United Kingdom (UK) household food waste levels increased from 7 million tonnes in 2012, to 7.3 million tonnes of food in 2015 at a monetary value of $£ 13$ billion per annum. Avoidable UK household food waste reduced by $21 \%$ between 2007 and 2012 (Smithers, 2017) then increased by 5.1\% to 4.4 million tonnes in 2015 (Quested and Parry, 2016). Individuals may not realise the impact that food waste has on the economy, the environment, and society often thinking because food is natural, and it simply rots into the ground (Doron, 2013). Domestic food waste largely ends up in landfill sites (Quested and Parry, 2011), where space is becoming increasingly scarce, especially as communities do not want new landfill sites a given area, due to environmental and aesthetic concerns (Barr, 2004). When food is placed into landfill the resources associated with the food are lost (Doron, 2013), including in the UK, 5,400 million cubic metres of water annually (Quested and Parry, 2011). In addition, methane, a potent greenhouse gas, that is 23 times stronger in terms of the environmental impacts than $\mathrm{CO}_{2}$, is produced when food starts to rot into the ground (Thermelis and Vlloa, 2007), whilst 19 million tonnes of $\mathrm{CO}_{2}$ is produced when manufacturing, distributing, storing and disposing of avoidable food waste (Doron, 2013).

Literature suggests two main motivators to encourage individuals to reduce food waste namely environmental concerns (Doron, 2013) and the monetary value associated with food waste (Lyndhurst, 2007; Graham-Rowe et al. 2014). These factors are important when considering the policy campaigns that have been developed to influence personal behaviour. Since 2009, a series of campaigns have been launched in the UK, by the government and supermarkets, with the aim of trying to reduce food waste levels (Quested and Parry, 2016). 
In 2005, the UK government launched the Courtauld Commitment, which is a voluntary agreement between major suppliers, manufacturers and supermarkets to improve resource efficiency and reduce waste. Subsequently, four stages of the agreement have been launched with future targets for 2025 to reduce food and drink waste by $20 \%$ (WRAP, not dated). In 2007, the UK government 'Love Food Hate Waste' (LFHW) campaign aimed to reach two audiences: firstly, the 15 million adults who are already aware, but need help in reducing the amount they waste, and secondly the remaining population who were identified as not being aware of food waste issues (Quested et al. 2012). It is difficult to determine the contribution of such campaigns to reducing food waste, because other concurrent socio-economic issues, can also play a part in food waste reduction. However recent research has suggested that appropriately targeted campaigns are of value (Schmidt, 2016; Delley and Brunner, 2017). The UK recession $(2008$ - 2012) caused food prices to rise by $14 \%$ whilst consumer income stayed static (Quested and Parry, 2011). As households had less disposable income, consumers started to pay more attention to perishable products like meat, as they could not afford to waste food (Quested and Parry, 2011; Miller and Branscum, 2012). Arguably this economic factor may have contributed to food waste reduction between 2007-2012, as equally as the impact of the LFHW campaign.

Food loss occurs at all stages of food production (Figure 1), but the further down the supply chain the food travels from the farm, the more costly it becomes to waste food as greater value has been added, both in monetary and environmental terms. This makes consumers and food retailers the most impactful food wasters in cost, society and environmental terms (Eriksson et al. 2015). Figure 1 illustrates the potential factors that contribute to the loss of food at different stages along the food supply chain.

\section{Take in Figure 1}

The literature demonstrates clearly that food waste is a global problem and a national problem too in the UK and that unless action is taken to engage individuals and encourage them to 
modify their behaviour then the social, environmental and economic impact will continue unchecked.

\section{Food waste behaviour and its impact on the quantities of food wasted}

Consumer food waste can be categorised into three different groups: avoidable, possible avoidable and unavoidable (Quested and Johnson, 2009). Unavoidable food waste includes inedible material that would not be consumed under normal conditions, for example, egg shells, fruit stones or animal and fish bones. Possible avoidable food waste is the food and drink material that some people eat, whilst others do not (Quested and Johnson, 2009:14). Alternatively avoidable food waste is classed as any food and drink product that was once edible, but now due to its current nature is no longer fit for consumption, such mouldy fruit (Quested et al. 2012; Eriksson et al. 2015). Table 1 outlines over the time period between 2007 and 2015 the quantity of the three aforementioned categories of household food waste in the UK.

\section{Take in Table 1}

The data shows a drop in avoidable food waste, but conversely a rise in unavoidable food waste over the time period. Factors influencing the quantity of food waste at the retail level that are within the scope of the business to address include: visual appearance of food at point of sale, over ordering, baking too much, handling fresh produce incorrectly and undertaking promotions on products that cause customers to over-buy when they are unlikely to consume the product (Stenmarck et al. 2011). Customers favour choice with fully stocked shelves, forcing supermarkets to over order and over stock, increasing the chances of food going out of date (Stuart, 2009; Stenmarck et al. 2011; Wyman, 2014) Furthermore, when supermarkets run promotions such as 'buy one get one free', consumers switch away from regularly purchases, to promotional offers, causing a variance in demand and increasing the chance of over purchase and subsequent spoilage (Quested et al. 2012; Wyman, 2014). Consumer buying patterns depend on additional factors too such as the weather, season, offers and 
118 of their customer offer in order to minimise food waste at retail level.

The 'good provider' describes individuals, who purchase large amounts of fruit and

120 vegetable and tend to overcook, as they feel they have failed if the family goes hungry, or 121 snacks on unhealthy food (Graham-Rowe et al. 2014; Quested and Luzecka, 2014; Mallinson 122 et al., 2016). 'Food recipients,' are those individuals who do not buy food for themselves and 123 live in the family home i.e. children and teenagers who, Graham - Rowe et al. (2014) argue, 124 are more likely to waste food, due to the lack of understanding of the monetary value of food. 125 Food waste in the family setting may also be in response to 'children being fussy'. Parents 126 are more likely to follow use by dates ${ }^{1}$, as they are concerned with the microbial safety issues 127 surrounding food products (Quested and Luzecka, 2014). The older generation, i.e. in their seventies and over, can be typed as the 'waste 129 intolerators'. They waste $25 \%$ less food compared to the rest of the population. They lived in 130 households with no tolerance of food waste, using up all the scraps and leftovers during the 131 food rationing in the Second World War (Quested et al. 2013) and greater levels of education 132 on food management and cooking (Godfray et al. 2010). This mindset has remained, even 133 though food is relatively cheaper than the past (Graham-Rowe et al. 2014). Conversely, 134 people lacking cooking skills and food storage knowledge are more concerned with the safety 135 risks involved with food, compared to those who do know how to cook and store food 136 correctly (Lyndhurst, 2007). The younger generation, i.e. aged 18-24, are said to be less 137 educated in terms of food, food storage and food waste, and scraps and leftovers are more 138 often thrown away due to them being perceived as being of little monetary value. Young 139 adults such as students, who have just moved out the family home, may not be able afford to

\footnotetext{
${ }^{1}$ The 'best before' date is associated with the quality (i.e. taste, texture, and aroma) and appearance of the product, which will slowly deteriorate after the date on the packaging, but it still safe to eat (Defra, 2011). Whereas the 'use by' date, is linked to the microbiological safety of the food product so after the 'use by date' has expired, the food could potentially cause illness (Defra, 2011).
} 
waste food, so they should in theory have greater awareness of the monetary value of food

141 waste (Graham - Rowe et al. 2014). Conversely, other literature suggests that the younger

142 generation, aged 18-24, are the highest food wasters within society (Hamilton et al. 2005;

143 Lyndhurst, 2007; Principato et al. 2015; Mallinson et al. 2016). The literature highlighted a

144 duality in findings with regard to student behaviour and no previous literature has considered

145 UK students specifically. This presented as the research gap that this empirical work is

146 designed to address. This paper is structured as follows: firstly an introduction to the topic of

147 study. The methodology of the empirical study is then outlined followed by the results, and 148 analysis. Key themes are discussed and conclusions and recommendations provided for 149 further research.

\section{3. Food waste and behaviours associated specifically with students}

There have been a few studies on the topic of food waste and the younger generation

152 including Italian and Spanish students (Graham-Rowe et al. 2014; Quested and Luzecka, 153 2014; Principato et al. 2015; Mondéjar-Jiménez et al. 2016). Principato et al. (2015) in their

154 Italian study with students $(\mathrm{n}=230)$ found the greater knowledge students had of the issues

155 surrounding food waste, the greater the chance of changing behaviour. However, in the study

156 students struggled to identify the specific environmental, social and economic issues linked to

157 food waste. Conversely, Graham - Rowe et al. (2014) determined that with students the 158 monetary value of food waste was a motivator.

In a further study, $6 \%$ of students were confused between 'best before,' and 'use by'

160 dates, and would throw the food away without a sensory evaluation (Principato et al. 2015).

161 Mondéjar-Jiménez et al. (2016) conducted an investigation to identify whether students in

162 Spain and Italy waste the same types of food. Table 2 shows the cultural difference in the 163 different types of food households waste on a weekly basis. For instance, on average Spanish 164 students wasted more white meat (14.75\%) on a weekly basis than Italian students (7.36\%). 165 Spanish students similarly wasted more convenience food $(12.82 \%)$ per week on average 166 compared to Italian students in the study (2.94\%). However, both countries, as with UK 
167 households, waste more fruit, bread and vegetables than any other type of food (Caswell,

168 2008; Brown et al. 2014; Mondéjar-Jiménez et al. 2016).

\section{Take in Table 2}

The literature explored to provide context for this study has identified a number of

171 factors that may influence students' food waste behaviour including: being time poor,

172 confused over duration dates and lacking awareness of the global issues related to food waste

173 Figure 2 provides a summary of these and other factors that influence students' food waste

174 awareness, and behaviour.

\section{Take in Figure 2}

176 There is a body of literature on food waste in the school food service, and canteen setting

177 (Ryley et al., 1979; Nicklas et al., 2013; Cohen et al., 2014; Hanks et al., 2014; Liu et al., 178 2016) and whilst this is not the focus of the study such studies indicate the challenges 179 associated with food waste and young people. Forty seven percent of 18-24 year olds in the 180 UK admit they lack knowledge when cooking and storing food in the kitchen (Sainsburys, 181 2016) and therefore are more likely to waste food when preparing, cooking and serving too 182 much. Universities in the UK are working with the LFHW campaign to help students when 183 they first move out of home, by giving advice on how to save money, gain greater skills in the 184 kitchen with simple recipes cards and advice on how to reduce food waste (Quested and 185 Luzecka, 2014), but students' awareness may not necessarily translate into actual behavioural 186 action. Awareness is defined for the means of this research as an individual's level of 187 knowledge, concern or interest in food waste and is a particular focus in this study.

\section{4. Methodology}

189 The aim of this research was to investigate the factors that frame student awareness and 190 behaviour associated with food waste. The study is exploratory in nature and the qualitative 191 data derived serves in terms of contextualising personal accounts of food waste awareness and 192 behaviour. The unit of analysis is therefore "the student", although the rationale for the 193 research recognises that the student does not exist in isolation, but is also influenced by the 
194 household in which they live in terms of both its facilities, and also the other individuals in

195 the household. Thus, in analysing the results it is important to consider that the units of

196 analysis are not independent as social factors at the household level may have an influence.

197 This issue of interdependence means that qualitative rather than quantitative methods were 198 used in this research.

199 The methodology outlined here cannot be considered to be grounded theory in its 200 purest sense as a literature review has been conducted prior to the data collection phase in 201 order to contextualise the research within existing knowledge (Cresswell, 2012), what is 202 important in developing theory and to formulate a research question which is of interest 203 namely:

204 What are the factors that an opportunity sample of UK students insinuate as being associated with their wastage of food?

However, the methodology has rather than a forcing approach followed an emerging, exploratory approach (Glaser, 1992) with the literature being used to position the research rather than inform its design in an alternative positivist approach. Constructivist grounded 210 theory means that the researcher is not neutral and the reflexive researcher's voice is thus 211 embedded within the methodology, through an active deliberation to prioritise primary data 212 analysis over and above the secondary data input via the literature (Ramalho et al., 2015).

\subsection{Interview design} Semi-structured interviews were undertaken with students $(n=50)$ who were enrolled 215 at a UK university living in 12 rented households, of between three and six people (Table 3) 216 to build a picture of the relationship between place, student awareness, behaviour and food 217 waste.

218 Take in Table 3 
A limitation of the study is the use of self-reporting by students and self-reporting might not

221 correlate to actual behaviour so face-to face interviews rather than an on-line survey was used

222 to seek to partially mitigate this factor. Dai et al. (2015) propose that interviews are well

223 established qualitative methods suited to explore the importance of factors of influence where

224 these have a complex interaction providing validity to the data but not indicating their relative

225 contribution nor distribution across the whole population rather than the reproducibility of a

226 quantitative data collection approach.

227

228

229

230

231

232

233

234

235

236

237

238

239

240

241

242

The interviews were conducted between February-March 2017, with one interviewer and one interviewee at a time to maximise comfort and to avoid stress, anxiety and discomfort, whilst taking into consideration the participants' body language as a means of improving the researcher's judgment on the response (Bryman and Bell, 2011). This approach also avoided response bias where participants might change their statements as might have occurred if a group interview approach had been used as individuals do not liked to be seen in a negative light or as exhibiting the "wrong" social behaviour by peers (Edmunds, 1999). A relaxed conversational approach was used, but still with an underlying purpose, direction and with prepared high level questions to use as a prompt if needed (see Appendix 1). The interviews were structured around six themes of potential influence that arose from the literature review element of the methodology: buying habits, kitchen, duration dates, monetary value, social consequences and environmental consequences. (This work included: Graham-Rowe et al. 2014; Principato et al. 2015; Quested and Luzecka, 2014; and Mondéjar-Jiménez et al. 2016).

All the interviews were recorded with the participant's permission and lasted an average of forty-five minutes. One pilot interview was conducted in order to refine and test the semi-structured questions and to gain an understanding of the validity and reliability of the data being collected (Saunders et al. 2012). No changes were made after the pilot interview so it formed the first of the interviews undertaken. Before the interviews were conducted, 
participants were required to read a brief containing details of the aim of the investigation, the

249 confidentiality of the results and a statement explaining that participants' had the right to

250 withdraw at any point and any result would be removed from further consideration. If

251 participants agreed to continue, the consent form was signed (Ritchie and Lewis, 2013). To

252 ensure participant privacy and confidentiality, anonymous interview coding was in recording

253 and transcripts. Participants were coded with the number of the interview.

\section{4.2. Interviewees and sampling procedure}

255 The interviewees were identified through a sampling strategy to include households firstly 256 with a range of mixed gender and single gender either all male or all female households and 257 secondly households of different sizes (see Table 3). Recruitment was via opportunity 258 sampling.

\section{$259 \quad 4.3$ Thematic analysis approach}

260 Qualitative data was collected and transcribed for each interview. The interview transcripts were coded to identify thematic categories associated with students' awareness and behaviour associated with food waste using NVivo version 11. Initial coding was undertaken and then secondary, tertiary and fourth level 'axial' coding to identify connections between concepts

264 and organisation of these into higher order and lower order themes and to demonstrate 265 relationships between concepts at each coding stage (Bazely and Jackson, 2013). A thematic map was developed to postulate how students' food waste awareness and behaviour is

267 influenced and to inform further study and theory development in this area.

\section{Results and Analysis}

270 This results are considered and analysed by primary theme. Fifty eight percent of the 271 participants were females, $42 \%$ were males, and $72 \%$ of the participants had never formally 272 studied food waste at university. The full household demographics can be seen in Table 3.

\section{$273 \quad$ 4.1 Buying habits}


Whether students cook and shop by themselves or as a household, is a key influence as to whether a shopping list is written, in advance. $43 \%$ of students in the study, who cook by themselves, do not write a shopping list, and $20 \%$ of students will only write a shopping list in accordance to the size of the shop. Two example student comments are as follows showing the variance in planning amongst the interviewees $(\mathrm{P}=$ participant number $)$ :

\section{'I just buy what I fancy when I am walking around the shop, I do not tend to follow a} shopping list, as [I] will never stick to it' (P16).

'If I am planning on doing a large shop, I will record down the essentials on my phone, but if I was doing a small shop then no, as I can usually just about remember what I need' (P31).

Thirty percent of students interviewed did write a weekly food shopping list, but $60 \%$ of those students shop and cook as a household and therefore are more organised. One response demonstrated this approach:

'We do all sit down, do an inventory of the cupboards, freezer and fridge and write down what we need, as there are more mouths to feed and food desires to meet.'(P24)

The literature demonstrates the value of pre-planning and then sticking to a list in order to reduce food waste. Consumers are tempted by promotions and end up buying and wasting more food than they actually need to (Quested et al. 2012). This was reinforced in this study by $17 \%$ of students highlighting that they failed to follow a shopping list due to the temptation of special offers. $22 \%$ of students interviewed stated they would buy foods on specials offer, knowing that they might not ever use the product. This could explain why in previous studies students spend 6\% more on weekly shops than the older generation (Mondéjar-Jiménez et al. 2016), because they are more easily influenced by such offers. Indicative statements made supporting this argument in this study included the following:

'... I think its great value for my money, but when it sits in my cupboard for a long period of time, I will throw them away, even if it's still in date' (P33).

'I should follow a shopping list and try and stick to it, but I always get tempted by promotions and discounts. For example, XXXX is closing down, and everything is reduced and half price,

but XXXX prices are so expensive especially for the quality. Anyway, as soon as I saw everything reduced, I went a bit crazy and brought nearly the whole shop, as I thought I was 
saving money. But my housemate pointed out to me that I did not really save much money, as YYYY is still cheaper than XXXX discounted prices. So I got tricked there' (P23).

Thus buying habits are a key behaviour that can influence student' food waste.

\subsection{Types of food wasted and influence of kitchen facilities}

Analysis of the results of the interviews highlights that $38 \%$ of students stated that they cook too much food; $32 \%$ did not use the food in time; $18 \%$ purchased too much food and $12 \%$ were influenced by duration dates. When asked what types of food were thrown away $58 \%$ of students stated they wasted vegetables. This was for three main reasons: $17 \%$ of students stated they buy too many varieties of vegetables on a weekly basis; $25 \%$ of students cook too much quantity; and $58 \%$ of the students do not use the vegetables up in time before they deteriorated e.g. through mould growth. Fruit was the second most wasted food product for $28 \%$ of students for two main reasons: $28 \%$ of students stated they buy too much on a weekly basis and $72 \%$ of students do not use the fruit in time. Milk was the third product stated to be wasted most often by $20 \%$ of respondents followed by pasta and potatoes both identified by $12 \%$ of respondents. In this primary research, none of the students stated bread was a source of waste and the pattern of food waste in terms of the type of food was different to the other student studies in the literature where fruit, vegetables and bread were the top three sources of food waste as food wasted once a week (Caswell, 2008; Brown et al. 2014; MondéjarJiménez et al. 2016 see Table 4).

\section{Insert Table 4}

Thirty-one percent of food waste is attributed to households cooking and preparing too much, and throwing away the left overs, instead of freezing or making it do for another meal (Quested et al. 2012). Consequently appropriate portion size is important (Graham-Rowe et al. 2014). The students in this study identified lack of freezer space as a factor that had a direct impact on the level of food waste. $20 \%$ of students stated they spent more on their weekly food bill, due to limited freezer space and having to for example: 

expensive' (P32).

'I like a bargain when I see one, especially going out of date meat, as it can be really expensive, but sometimes I am unable to buy it, as there is no freezer room available and I know I won't eat it during the week as I have other food to use up' (P1).

'...sometime I cook too much curry but there is enough for another meal, but I do not have the room to freeze it, which means I have to have it the next day but I always fancy something else, rather than leftovers. So the leftovers do eventually end up in the bin' (P34).

The lack of appropriate kitchen facilities therefore influences behaviour. One respondent explained

'I have noticed, within our communally shops, [communal shopping as a household] we waste less, as we always make sure whatever needs using in the fridge is used up first. Compared to when we do our lunches separately, more food is thrown away, as individuals will eat what they fancy rather than what needs using up. For example, my housemate had a full bag of lettuce in the fridge that was just on turning point, but was still ok to eat, but it needed using ASAP, but instead of making a sandwich or a salad, she chose to walk into town and bought a XXXX [sandwich from a shop], as she couldn't be bothered to make any lunch.

Then the next she day complained that her salad had gone off' (P36).

Indeed, $46 \%$ of students in the study said that what they preferred to eat on a given food occasion overcame their thoughts on the need to eat leftovers. This concurred with previous research on consumption of leftovers by Lyndhurst, (2007).

\subsection{Student awareness of duration dates}

Research suggests that $13 \%$ of consumers believe food packaging has a role in the home, but lack awareness of how packaging keeps produce fresh for longer, prevents dehydration and provides valuable information on storage and cooking (Plumb et al. 2013). Principato et al. (2015) suggest that those who have greater food knowledge, have a better chance to change food waste behaviour. The primary research identified that half of the students interviewed (50\%) knew the difference between the two types of duration date coding. $22 \%$ of the students interviewed did not know the difference between the two duration date systems and $28 \%$ of students acknowledged the 'use by' dates refers to the safety of the food product, but had no understanding of the 'best before' date. Forty-six percent of students in the study will throw away meat on the 'use by' date, due to their knowledge of increased risk of food 
poisoning. At the same time these students do not follow the duration dates on fresh produce,

as they perceive there is a lower food safety risk.
'I do not trust food after the duration dates on packaging, especially meat as I have had food poisoning several times.' (P14)

'Depends on what it is. I do not follow dates of fruit and vegetables, as they will never give you food poisoning, due to the risk of food poisoning. But on dairy products and meat I try and make sure the food product is used in time, otherwise it goes in the bin as I do not want to risk getting ill.' (P32)

For $22 \%$ of students, this behaviour was identified as being down to parental influence as shown in the next two indicative quotes:

'I adopt all my cooking skills from my parents, and parents have always said do not eat meat after the duration dates, due to the safety and increased risk of getting food poisoning' (P20).

'My parents have always told me to waste food when it comes to the use by date, especially meat products, due to the risk of food poisoning. So I usually bin meat and dairy products on the use by date, but things like vegetable I will just keep until they have started to turn mouldy' (P22).

This theme shows the link between an individual's awareness and their associated food behaviour.

\subsection{Student awareness of monetary value of food waste}

Thirty two percent of students questioned stated they were more inclined to waste fruit and vegetables than other food items, as they believed them in terms of monetary value as being cheap and readily available. On the other hand, the same proportion of students were less inclined to waste meat.

'.....You can go to XXXX and buy a bag of carrots for 40p, which, if you end up wasting them, you are only wasting $40 p$ which is not going to break the bank' (P25).

'If I knew the exact total amount of the monetary value of the food I waste I waste was, then probably yes. But as the same food is so cheap today, you can pick up a bag of vegetables for under a £1, so I am probably not wasting huge amounts of money'(P34).

The awareness factors identified by the respondents that they used when considering the monetary value of food waste was firstly that food was cheap;

\section{'if I was going to waste anything, I would waste the vegetables as they are the cheapest} component of a meal' (P10). 
(concurring with Principato et al., 2015);

'as the money has already gone out the bank account when the products are purchased in the supermarkets.... it does not matter if the products are thrown in the bin...' (P9).

$28 \%$ of the students interviewed believed money was only wasted when huge portions of

food were thrown away in one sitting.

'I know you are wasting money every time you throw food away, but when I waste small amounts, like a handful of peas, then no I don't believe you are, or it never crosses my mind. As it is only worth 10p or something' (P46).

'Even though I am very conscious about the price of food when I go shopping, when I waste food it never crosses my mind that wasting food is wasting money, as you only waste little bits here and there, you are never wasting whole meals' (P41).

\section{Many interviewees failed to comprehend the accumulative monetary value of food waste}

and were surprised how the value accrued over a monthly or on a yearly basis.

'Wow, I have never thoughts about how much it all adds up to, and $£ 162$ is a lot of money for throwing away in a year, as I could do so much more with that money, rather than just throwing it in the bin' (P32).

'....I only waste small amounts of food. Maybe around $£ 5$ a week..... Wow $£ 25$ a month and roughly $\$ 300$ a year is a lot of money wasted of food waste. I have never thought about it like that, as the $£ 300$ is not taken straight out of your account as a hump sum. Also you do not even see the monetary value of food waste coming out of my account, as it is a part of your grocery shop' (P5).

'I honestly didn't think $£ 5$ a week was a lot, as I only waste small portions of cheap food here and there. But when you put it like that I am wasting huge amounts of money that could be better spent. Also when I waste food, I never perceive it as wasting money, as the money has already left your bank account' (P20).

These indicative comments demonstrate a lack of awareness of the impact of food waste and a disconnect between the monetary impact associated with their levels of personal food waste. Some respondents stated that saving money in itself was not necessarily a motivator to waste less food:

'Maybe if I run out of money.' (P10)

'Yes I guess it would be if I had no money...' (P22)

'If food becomes more expensive then yes.' (P25) 
The financial threshold that was a motivator to save money also varied between students and

456 for some saving two pounds a week was a motivator where for others it was not. The notion

457 of the influence of monetary value as a motivator for behavioural change with food waste is 458 worthy of further study as here the impact is unclear.

\section{$459 \quad 5.5$ Student awareness of the environmental impact of food waste}

460 The research indicates that students have a mixed degree of awareness of the environmental

461 consequences of food waste. Overall, $61 \%$ of students were conscious of the environmental 462 implications, especially those who had studied food topics as party of their university course.

463 Twenty-three percent of respondents in the study agreed with P1 that 'Food is natural so 464 surely it just rots down into the ground' supporting the findings of Doron (2013). Similarly, $46522 \%$ of students concurred that 'Food packaging ending up in landfills instead of being 466 recycled' (P44) was the biggest environmental issue relating to food waste.

\section{$467 \quad 5.6$ Student awareness of the social impact of food waste}

468 The negative social impact of food waste are that if food is wasted this influences the balance 469 between supply and demand causing food prices to rise impacting those on a low income. 470 Conversely if surplus food is identified, collected and distributed to those who are food 471 insecure this can have a positive impact towards their lives both personally and at the 472 community level. An example of such social impact are the replacement of free school meals 473 during school holidays where parents cannot afford the cost of the lunch. As with 474 environmental impact, the social impact of food waste was not a strong motivator for the 475 students that were interviewed to influence behaviour. Fifty-four percent of respondents 476 lacked awareness and struggled to identify the social cost of food waste and only $14 \%$ firmly 477 associated the social implications of food waste behaviour with wasting food. Just under a 478 quarter of students mentioned people living in poverty or charities helping those in need, but 479 with a greater proportion believing that the world will not run out of food. Individual 480 indicative comments included: 

have to increase by $40 \%$ to meet this demand. But also the fact there are thousands of families and children in poverty who cannot afford food' (P36).

484

485

486

487

488

489

490

491

492

493

494

495

496

497

498

499

500

501

502

503

504

505

506

507

508

509 inclined to waste fruit and vegetables, due to their perception that they were of little monetary value, but were less inclined to waste meat, as it was seen to be the most expensive part of 516 any meal.

'Maybe in the very long term, vegetables may go back to seasonal, and with increased climate change, there may be a shortage like we are seeing in Spain at the moment, but we will never run out of food as there is always technology and $3 D$ printing' (P10).

'I honestly do not know, they do say food production will have to increase to meet the growing demand, but I personally do not think we will. I mean look how readily available it is today and so much food is produced by technology. Maybe with the current climate change, and food .. shortages, we may go back to seasonal produce, instead of all year round fruit and vegetables. But the world will never run out of food' (P23).

'....technology forever increasing, like the development of $3 D$ printers, and will save us if we were going to run out of food' (P26).

'... there may be a shortages of fresh produce..... and fresh produce will become more seasonal. But no, I don't think the world will ever run out of food, have you seen how much food is on the supermarket shelves and how much we import '(P6).

Respondents highlighted some degree of optimism that technology would prevent food shortages, but as a consequence of climate change, one third of respondents (32\%) stated that fresh produce would become more seasonal.

\subsection{Primary motivators that influence food waste}

In this study, not one student highlighted the environment as a primary motivator to change food waste behaviour concurring in part with the work of Principato et al. (2015). The world running out of food was identified as a factor of influence by one in ten of the respondents in this study. The lack of motivation associated with social or environmental concerns meant that for $34 \%$ of respondents saving money was the primary, albeit limited motivator, especially when as a result of the interview process, they became more aware of the monetary impact of their behaviour. The students interviewed could roughly estimate the monetary value of their level food waste within a given week. Respondents were more 
518 rise in food price were identified as motivators to change behaviour. $16 \%$ of respondents said

519 that being too busy was a barrier to changing behaviour and reducing food waste. Sources

520 such as Quested and Luzecka (2014) suggest that the younger generation implied being too

521 busy and having more important priorities to worry about than changing food waste

522 behaviour. Additional factors were suggested in the interviews as potential ways to motivate

523 students to waste less food including: reduced pack size, single duration dates rather than the

524 current system of multiple duration codes, and improved food safety. Some of the 525 respondents' indicative comments that underpin this summary of findings are collated (Table $5265)$

\section{Take in Table 5}

There was a full second, third and fourth level axial coding undertaken (Table 6) that informed the development of a thematic map (Figure 3). The thematic map takes the six

531 themes of buying habits, kitchen facilities, student awareness of duration dates, monetary

532 value, environmental impacts and social impacts and adds a seventh theme of knowledge of 533 food in its wider sense.

\section{$534 \quad$ Take in Table 6 and Figure 3}

537 explores the interconnection between factors of influence and student awareness and 538 behaviour associated with food waste found in the research. Figure 3 reflects the seven 539 superordinate factors of influence towards students' food waste behaviour, and sub-ordinate 540 factors that influence student awareness such as parental or household influence, and 541 awareness of monetary, environmental or social impact. The implications of the findings of 542 this study are now discussed.

\section{5. Discussion}


545 Previous literature has considered both plate waste in the food service setting (Cohen et al.,

546 2014; Falasconi et al., 2015) and also individual households in the household level setting, the

547 unit of analysis for this study. Students were identified are most likely to waste food when

548 preparing, cooking and serving too much food leading food waste campaigns to focus solely

549 on tools such as recipe cards when trying to educate students (Quested and Luzecka, 2014).

550 However, the thematic map developed through this study demonstrates multiple, complex and

551 nuanced influences behind students' food waste behaviour when purchasing, preparing,

552 cooking and serving their own food. At one level a lack of freezer space, students eating what

553 they fancy rather than making use of leftovers, not creating or following a shopping list, the

554 temptation of special offers in store and then not using food up in time, all influence

555 behaviour. The level of awareness of multiple duration dating systems and what they mean in

556 terms of food safety also are factors of influence. The students who have been raised by food

557 safety conscious parents have adopted the same food waste behaviour habits. Therefore the

558 influence of parents' food waste behaviour on their children's food waste behaviour later in

559 life is worthy of further study.

560 There are some limitations to this study in terms of the sample group being students

561 and thus this limits wider generalisation to the whole population. The sampling strategy was

562 based on a convenience approach, but this has provided a thematic map worthy of further

563 research using a quantitative methodology that has greater validity in terms of the inference

564 that can be drawn.

$565 \quad$ Four barriers were noted in this work and others that influence awareness or behaviour

566 associated with food waste: being too busy or having more important priorities (see too

567 Quested and Luzecka, 2014); believing money is only wasted when huge portions of foods

568 are thrown away in one sitting; not being able to visualise the monetary value of food waste

569 as part of the overall grocery bill and finally that cheap food is so readily available. For

570 students in this study, there was limited cognitive connection between reducing personal food 
571 waste today in order to reduce the degree of food crisis in the future or indeed the impact of

572 food waste on the climate. In fact this study would suggest that for the respondents sampled

573 there is little worry or concern for the environmental and social consequences of food waste

574 now or for future generations. This may in part be due to a lack of awareness, but also it could

575 be as a result of other priorities being seen as more important or more pressing, returning to

576 notions of being too "busy". This suggests that there is a cognitive filtering occurring where

577 food waste as being seen as less important or more distant compared with other more

578 immediate concerns and this is worthy again of further study to identify how to make food 579 waste less cognitively distant as a concern for young people.

580 Steg and Vlek (2009) considered the factors that promote or inhibit environmental

581 behaviour namely perceived cost and benefit, moral and normative concerns and effect. They

582 note too that availability of facilities and intra-personal factors play a role such as habits also

583 a feature of this work. This research shows that individual levels of awareness actually 584 mediate the influence of these factors and as a result the environmental behaviour that is 585 exhibited. Steg and Vlek (2009) suggest that environmental behavioural change can be driven 586 by informational strategies, and structural strategies that reward good behaviour and punish 587 bad behaviour. This was not a research objective for this study but in future research the use 588 of incentives could be considered as well as developing the methodology to overcome the 589 limitations described above.

\section{Conclusions}

This research has clearly demonstrated there are multiple influencers of students' food

592 waste behaviour making the issue a complex one to effectively tackle. Lack of awareness of

593 the economic, environmental and social costs of food waste and an attitude of being 'too busy

594 to care' also play a part. As a result, it is vital to address student food waste from multiple 595 angles, including when students first come to university creating wider awareness of the 596 personal, environmental and social impact of food waste. Communication and policy tools 597 aimed at the young need to reflect these factors and also recognise that in short-term rented 
accommodation the facilities that the students have in terms of kitchen space, especially

599 freezer space can limit behavioural options. Future research should look to expand this study

600 to encompass a larger sample size of students.

601

602

603

604

605

606

607

608

609

610

611

612

613

614

615

616

617

618

619

620

621

622

623

624

625

626

627

\section{References}

Barr, S. 2004. What we buy, what we throw away and how we use our voices - Sustainable household waste management in the UK. Sustainable development, $1^{\text {st }}$ February, 32-44.

Bazely, P. Jackson, K. 2013. Qualitative data analysis with Nvivo. London: Sage.

Bond, M. Meacham, T. Bhunnoo, R. Benton, T.G. 2013. Food waste within global food systems. A Global Food Security report. [Online]. Global Food Security. Available from: http://www.foodsecurity.ac.uk/assets/pdfs/food-waste-report.pdf 2. [Accessed $1^{\text {st }}$ December 2016].

Brown, T., Hipps, N.A., Easteal, S., Parry, A. Evans, J.A., 2014. Reducing domestic food waste by lowering home refrigerator temperatures. International Journal of Refrigeration, 40, 246-253.

Bryman, A. Bell, E. 2011. Business research methods. 3rd ed. Oxford: Oxford University Press.

Caswell, H. 2008. Britain's battles against food waste. Nutrition Bulletin, 33(4), 331-335.

Cohen, J.F.W., Richardson, S., Parker, E., Catalano, P.J., Rimm, E.B., 2014. Impact of the New U.S. Department of Agriculture School Meal Standards on Food Selection, Consumption, and Waste. Am. J. Prev. Med. 46, 388-394.

Creswell, J. 2012. Qualitative inquiry and research design: Choosing among five approaches. Los Angeles, CA: Sage.

Dai, Y.C. Gordon, M.P.R. Ye J.Y. Xu, D.Y. Lin, Z.Y. Robinson, N.K.L. Woodard, R. Harker, M.K. 2015, Why doorstepping can increase household waste recycling. Resources, Conservation and Recycling, 102, 9-19

Defra. 2011. Guidance on the application of date labels to food. [Online]. Defra. Available from:https://www.gov.uk/government/uploads/system/uploads/attachment_data/file/69316/pb 132629-food-date-labelling-110915.pdf. [Accessed $18^{\text {th }}$ December 2016].

Delley, M. Brunner, T.A., 2017. Foodwaste within Swiss households: A segmentation of the population and suggestions for preventive measures. Resources, Conservation and Recycling, $122,172-184$.

Doron. 2013. Waste Not, Want Not: How Fairness Concerns Can Shift Attitudes to Food Waste. Fabian Society. Available from: http://www.fabians.org.uk/wpcontent/uploads/2012/05/Fabian_Waste_Pamphlet_5.12_web.pdf [Accessed $25^{\text {th }}$ September 2016].

Edmunds, H. 1999. The focus group research handbook. Lincolnwood: NTC Business Books. 
Eriksson, M., Strid, I. Hansson, P.A., 2016. Food waste reduction in supermarkets-Net costs and benefits of reduced storage temperature. Resources, Conservation and Recycling, 107, 73-81.

Falasconi, L., Vittuari, M., Politano, A., Segrè, A., 2015. Food Waste in School Catering: An Italian Case Study. Sustainability 7, 14745-14760.

653

FAO (Food Agriculture Organisation) 2017, Food wastage,: Key facts and fingers, Available

Glaser, B. (1992). Basics of grounded theory analysis. Mill Valley, CA: Sociology Press.

Godfray, H.C.J., Beddington, J.R., Crute, I.R., Haddad, L., Lawrence, D., Muir, F.F., Pretty, J., Robinson, S., Thomas, S.M. Toulmin, C. 2010. Food security: The challenge of feeding 9 Billion people. Science, 327 (5967), 812-818.

Graham-Rowe, E., Jessop, D.C. Sparks, P., 2015. Predicting household food waste reduction using an extended theory of planned behaviour. Resources, Conservation and Recycling, 101, 194-202.

Graham-Rowe, E., Jessop, D.C. Sparks, P., 2014. Identifying motivations and barriers to minimising household food waste. Resources, Conservation and Recycling, 84, 15-23.

Gunders, D. 2012. Wasted: How America is losing up to 40 percent of its food from farm to fork to landfill. Natural Resources Defence Council, 28 August, pp.1-26.

Hamilton, C. Denniss, R. and Baker, D.G. 2005. Wasteful consumption in Australia. Australia: Australia Institute.

Hanks, A.S., Wansink, B., Just, D.R., 2014. Reliability and accuracy of real-time visualization techniques for measuring school cafeteria tray waste: validating the quarter-waste method. J. Acad. Nutr. Diet. 114, 470-4.

Kosseva, M. and Webb, C. eds., 2013. Food industry wastes: assessment and recuperation of commodities. Academic Press.

Liu, Y., Cheng, S., Liu, X., Cao, X., Xue, L., Liu, G., 2016. Plate Waste in School Lunch Programs in Beijing, China. Sustainability 8, 1288.

Lyndhurst. 2007. Food Behaviour Consumer Research: Quantitative Phase. [Online]. WRAP. Available from:

http://www.wrap.org.uk/sites/files/wrap/Food\%20behaviour\%20consumer\%20research\%20q uantitative\%20jun\%202007.pdf. [Accessed 28 ${ }^{\text {th }}$ November 2016].

Mallinson, L.J., Russell, J.M. Barker, M.E., 2016. Attitudes and behaviour towards convenience food and food waste in the United Kingdom. Appetite, 103, 17-28.

Miller, C.K. Branscum, P., 2012. The effect of a recessionary economy on food choice: implications for nutrition education. Journal of Nutrition Education and Behaviour, 44(2), 697 
Mondéjar-Jiménez, J.A., Ferrari, G., Secondi, L. Principato, L., 2016. From the table to waste: An exploratory study on behaviour towards food waste of Spanish and Italian youths. Journal of Cleaner Production, 138, 8-18.

Nicklas, T.A., Liu, Y., Stuff, J.E., Fisher, J.O., Mendoza, J.A., O'Neil, C.E., 2013.

Plumb, A. Downing, P. and Parry, A. 2013. Consumers attitudes towards food waste and food packaging. [Online]. WRAP, Available from:

http://www.wrap.org.uk/sites/files/wrap/Report\%20-

$\% 20$ Consumer $\% 20$ attitudes $\% 20$ to $\% 20$ food $\% 20$ waste $\% 20$ and $\% 20$ packaging $0 . p d f$. [Accessed $5^{\text {th }}$ December 2016].

Principato, L. Secondi, L. Pratesi, C.A. (2015). Reducing food waste: an investigation on the behaviour of Italian youths. British Food Journal, 117(2), 731-748.

Quested and Parry. 2016. Household Food Waste in the UK, 2015. [Online]. Wrap. Available from:

http://www.wrap.org.uk/sites/files/wrap/Household_food_waste_in_the_UK_2015_Report.pd f. [Accessed $18^{\text {th }}$ January 2017].

Quested, T. and Luzecka, P. 2014. Household food and drink waste: A people focus. [Online]. WRAP. Available from: http://www.wrap.org.uk/sites/files/wrap/Peoplefocused\%20report\%20v6_5\%20full.pdf. [Accessed 10 ${ }^{\text {th }}$ November 2016].

Quested, T.E., Marsh, E., Stunell, D. Parry, A.D., 2013. Spaghetti soup: The complex world of food waste behaviours. Resources, Conservation and Recycling, 79, 43-51.

Quested, T., Ingle, R. and Parry, A. 2012. Household food and drink waste in the United Kingdom 2012. [Online]. WRAP. Available from:

http://www.wrap.org.uk/content/household-food-and-drink-waste-uk-2012. [Accessed 16th October 2016].

Quested, T. and Parry, A., 2011. New estimates for household food and drink waste in the $U K$. [Online]. WRAP. Available from:

http://www.wrap.org.uk/sites/files/wrap/New\%20estimates\%20for $\% 20$ household $\% 20$ food $\% 2$ 0and $\% 20$ drink $\% 20$ waste $\% 20$ in $\% 20$ the $\% 20$ UK $\% 20$ FINAL $\% 20$ v2 $\% 20$ (updated $\% 207$ thAugus t2012).pdf. [Accessed $3^{\text {rd }}$ October 2016].

Quested, T. and Johnson, H. 2009. Household food and drink waste in the UK. [Online]. WRAP. Available from: http://www.wrap.org.uk/sites/files/wrap/Household_food_and_drink_waste_in the_UK_report.pdf. [Accessed 16th October 2016].

Ramalho, R., Adams, P., Huggard, P. and Hoare, K., 2015, September. Literature review and constructivist grounded theory methodology. In Forum: Qualitative Social Research 16, 3. Freie Universität Berlin.

Ritchie, J. and Lewis, J. 2013. Qualitative research practice, a guide for social science students and researcher. London: Sage. 
Sainsbury's, 2016. Modern life is rubbish, Lifting the lid of food waste habits in Britain today.

[Online]. Sainsbury's. Available from: http://www.jsainsbury.co.uk/media/3366413/Modern\%20Life\%20is\%20Rubbish\%20Sainsburys\%20Repo rt.pdf. [Accessed $1^{\text {st }}$ November 2016).

Saunders, M., Lewis, P. and Thornhill, A. 2012. Research methods for business students. 6th ed. Harlow: Pearson.

Schmidt, K., 2016. Explaining and promoting household food waste-prevention by an environmental psychological based intervention study. Resources, Conservation and Recycling, 111, 53-66.

Smithers. 2017. UK throwing away £13bn worth of food each year, latest figure show. [Online]. The Guardian. Available from: https://www.theguardian.com/environment/2017/jan/10/uk-throwing-away-13bn-of-foodeach-year-latest-figures-show. [Accessed $10^{\text {th }}$ January 2017].

Stenmarck, A., Jensen, C., Quested, T., Moates, G., Buksti, M., Cseh, B., Juul, S., Parry, A., Politano, A., Redlingshofer, B. Scherhaufer, S., 2016. Estimates of European food waste levels. [Online]. Fusion. Available from: http://www.eufusions.org/phocadownload/Publications/Estimates\%20of\%20European\%20food\%20waste\% 20levels.pdf. [Accessed 10th October 2016].

Steg, L. and Vlek, C., 2009. Encouraging pro-environmental behaviour: An integrative review and research agenda. Journal of environmental psychology, 29(3), 309-317.

Stenmarck, Å., Jörgen Hanssen, O., Silvennoinen, K., Katajajuuri, J.M. Werge, M., 2011. Initiatives on prevention of food waste in the retail and wholesale trades. [Online]. Swedish Environment Research Institute. Available from: http://www.ivl.se/download/18.343dc99d14e8bb0f58b75fc/1445517505356/B1988.pdf [Accessed 10th October 2016].

Stuart, T. 2009. Waste - Uncovering the global food scandal. London: W.W. Norton and Company.

Themelis, N.J. Vlloa, P.A. 2007. Methane generation in landfills. Renewable energy, 32(7), 1243-1252.

WRAP. Not dated. The Courtauld Commitment. [Online]. WRAP. Available from: http://www.wrap.org.uk/node/14507. [Accessed $29^{\text {th }}$ October 2016).

Wyman. 2014. Reducing food waste, how retailers can help? [Online]. Marsh and McLennan Companies. Available from: http://www.oliverwyman.com/content/dam/oliverwyman/global/en/2014/jul/OW_Reducing_Food_Waste.pdf. [Accessed $3^{\text {rd }}$ October 2016].

Young, W., Russell, S.V., Robinson, C.A. Barkemeyer, R., 2017. Can social media be a tool for reducing consumers' food waste? A behaviour change experiment by a UK retailer. Resources, Conservation and Recycling, 117, 195-203. 
803

804

805

806 
808 Participant's Code Number:

809 Household Code:

810 Date and Time visited:

\section{Background Information}

- Gender - Female/ Male

- What course are you studying?

- Have you studied the topic of food waste as a part of your university course? Yes/No

\section{Household Questions}

(Questions will vary depending on whether the student eat and shop as a household, individual or both)

- How many students do you live with, including yourself?

- Do you shop as a household, individually or both?

- Do you eat as a household, individually or both?

- How does the sharing of the kitchen food cupboards work? Do you communally share? Or do have limited space each?

- How does sharing of the freezer work? Do you communally share or have a limited space each?

- How does sharing of the fridge work? Do you communally share or have a limited space each?

- Does your kitchen space or the equipment you have to cook limit you in terms of how you buy food?

\section{Buying Habits}

(Questions will vary depending on whether the student eat and shop as a household, individual or both)

- If you shop as a household, individual or both how do you decide what food to buy?

- When shopping as a household, individual or both, do you tend to do an inventory of your food cupboards/ fridge/ freezer?

- When you shop as a household, individual or both, do you shop with a shopping list?

- When shopping as a household, individual or both, do you buy certain food on special offer knowing that you might never use it?

\section{Kitchen}

- When eating as household, individual or both, how do you decide what you are going to eat?

- Why do you personally throw away food? 
- When you cook too much, as a household, individual or both, what do you do with the leftover food?

- What types of food do you usually find yourself throwing away?

\section{Duration Dates}

- What does the best before date on a food indicate?

- What does the use by date on a food indicate?

- What do you do when a food product goes past the best before date on the label?

- What do you do if a food product goes past the use before date on the label?

\section{Monetary Value of Food Waste}

- Are you aware of the monetary value of food you buy? e.g. an average price for a $250 \mathrm{~g}$ block of cheese.

- Do you believe you are wasting money when throwing food away?

- Could you calculate the monetary value of the food you throw away?

- If so, on a weekly basis, what is the monetary value of the food you throw away?

- Is saving money a motivation that encourages you to waste less food?

\section{Environmental and Social Impacts of Food Waste}

- Are you aware of the environmental impacts of food waste?

- What do you consider to be the most important aspects?

- Are you aware of the social impacts of food waste?

- What do you consider to be the most important aspects?

\section{Conclusion Questions}

- As a student what is the primary factor that would encourage you to waste less of the food that you buy?

- What other factors would encourage you to waste less food?

- As a result of this interview what steps, if any, are you prepared to take to reduce:

- Personal food waste

- Household food waste

Thank you very much for taking the time to speak with me today. 
Table 1: 2012-2015 UK household food waste. (Figures rounded to the nearest thousand tonnes).

\begin{tabular}{|l|l|l|l|l|l|}
\hline & $\mathbf{2 0 0 7}$ & $\mathbf{2 0 1 0}$ & $\mathbf{2 0 1 2}$ & $\mathbf{2 0 1 4}$ & $\mathbf{2 0 1 5}$ \\
\hline Avoidable & 5,342 & 4,299 & 4,221 & 4,480 & 4,436 \\
\hline Possibly avoidable & 1,433 & 1,226 & 1,203 & 1,277 & 1,264 \\
\hline Unavoidable & 1,521 & 1,575 & 1,598 & 1,620 & 1,633 \\
\hline Total & 8,296 & 7,100 & 7,022 & 7,377 & 7,333 \\
\hline
\end{tabular}

909

910 Table 2: Types of foods wasted once a week by Itailian and Spanish students as 911 percentage values. (Adapted from Mondéjar-Jiménez et al., 2016)

\begin{tabular}{|l|c|c|}
\hline Types of Food & $\begin{array}{c}\text { Italian } \\
\text { students }\end{array}$ & $\begin{array}{c}\text { Spanish } \\
\text { students }\end{array}$ \\
\hline Fruit & 41.90 & 37.82 \\
\hline Bread & 36.03 & 38.46 \\
\hline Vegetables & 33.82 & 25.00 \\
\hline Pasta & 21.32 & 10.90 \\
\hline Eggs & 16.18 & 10.25 \\
\hline Salted Snacks & 9.56 & 15.38 \\
\hline White Meat (Turkey, Chicken) & 7.36 & 14.75 \\
\hline Yogurt & 5.15 & 7.69 \\
\hline Milk & 4.42 & 3.84 \\
\hline Dairy Products & 3.68 & 3.20 \\
\hline Convenience Food & 2.94 & 12.82 \\
\hline Precooked Foods & 2.94 & 12.18 \\
\hline Processed Meat & 2.21 & 7.69 \\
\hline Red Meat & 2.21 & 5.77 \\
\hline Cheese & 2.21 & 4.49 \\
\hline Sweet Snacks & 2.21 & 3.20 \\
\hline Frozen Foods & 1.48 & 3.85 \\
\hline Fish & 0.74 & 5.77 \\
\hline Butter and other Fats & 0.74 & 3.84 \\
\hline
\end{tabular}




\begin{tabular}{|c|c|c|c|c|}
\hline Household No. & Participant No. & Gender & $\begin{array}{l}\text { Household } \\
\text { Size }\end{array}$ & $\begin{array}{l}\text { Studied Food } \\
\text { Waste }(\mathbf{Y} / \mathbf{N})\end{array}$ \\
\hline H1 & $\mathrm{P} 2$ & $\mathrm{~F}$ & 4 & $\mathrm{Y}$ \\
\hline $\mathrm{H} 1$ & P6 & M & 4 & $\mathrm{~N}$ \\
\hline $\mathrm{H} 1$ & P8 & M & 4 & $\mathrm{~N}$ \\
\hline $\mathrm{H} 1$ & P31 & $\mathrm{F}$ & 4 & $\mathrm{Y}$ \\
\hline $\mathrm{H} 2$ & $\mathrm{P} 4$ & $\mathrm{~F}$ & 5 & $\mathrm{~N}$ \\
\hline $\mathrm{H} 2$ & P5 & M & 5 & $\mathrm{~N}$ \\
\hline $\mathrm{H} 2$ & $\mathrm{P} 32$ & $\mathrm{~F}$ & 5 & $\mathrm{~N}$ \\
\hline $\mathrm{H} 2$ & P33 & M & 5 & $\mathrm{~N}$ \\
\hline $\mathrm{H} 2$ & P34 & M & 5 & $\mathrm{~N}$ \\
\hline $\mathrm{H} 3$ & P7 & $\mathrm{F}$ & 6 & $\mathrm{Y}$ \\
\hline $\mathrm{H} 3$ & $\mathrm{P} 10$ & $\mathrm{~F}$ & 6 & $\mathrm{~N}$ \\
\hline $\mathrm{H} 3$ & P11 & $\mathrm{F}$ & 6 & $\mathrm{~N}$ \\
\hline $\mathrm{H} 3$ & $\mathrm{P} 12$ & $\mathrm{~F}$ & 6 & $\mathrm{~N}$ \\
\hline $\mathrm{H} 3$ & $\mathrm{P} 35$ & $\mathrm{~F}$ & 6 & $\mathrm{~N}$ \\
\hline $\mathrm{H} 3$ & P36 & $\mathrm{F}$ & 6 & $\mathrm{Y}$ \\
\hline $\mathrm{H} 4$ & P9 & $\mathrm{F}$ & 4 & $\mathrm{~N}$ \\
\hline $\mathrm{H} 4$ & P43 & $\mathrm{F}$ & 4 & $\mathrm{Y}$ \\
\hline $\mathrm{H} 4$ & P44 & $\mathrm{F}$ & 4 & $\mathrm{~N}$ \\
\hline $\mathrm{H} 4$ & P45 & $\mathrm{F}$ & 4 & $\mathrm{~N}$ \\
\hline $\mathrm{H} 5$ & $\mathrm{P} 13$ & M & 4 & $\mathrm{~N}$ \\
\hline H5 & P14 & $\mathrm{F}$ & 4 & $\mathrm{~N}$ \\
\hline $\mathrm{H} 5$ & P15 & $\mathrm{F}$ & 4 & $\mathrm{Y}$ \\
\hline $\mathrm{H} 5$ & P16 & M & 4 & $\mathrm{~N}$ \\
\hline H6 & P17 & M & 3 & $\mathrm{~N}$ \\
\hline H6 & P18 & $\mathrm{M}$ & 3 & $\mathrm{~N}$ \\
\hline H6 & P19 & $\mathrm{M}$ & 3 & $\mathrm{~N}$ \\
\hline H7 & P20 & $\mathrm{F}$ & 5 & $\mathrm{Y}$ \\
\hline H7 & P21 & $\mathrm{F}$ & 5 & $\mathrm{~N}$ \\
\hline $\mathrm{H} 7$ & P22 & $\mathrm{F}$ & 5 & $\mathrm{~N}$ \\
\hline $\mathrm{H} 7$ & $\mathrm{P} 23$ & $\mathrm{~F}$ & 5 & $\mathrm{~N}$ \\
\hline H7 & P46 & F & 5 & $\mathrm{Y}$ \\
\hline H8 & P24 & $\mathrm{M}$ & 3 & $\mathrm{~N}$ \\
\hline H8 & P25 & $\mathrm{M}$ & 3 & $\mathrm{~N}$ \\
\hline H8 & P26 & $\mathrm{M}$ & 3 & $\mathrm{~N}$ \\
\hline H9 & P27 & $\mathrm{F}$ & 4 & $\mathrm{Y}$ \\
\hline H9 & P28 & $\mathrm{F}$ & 4 & $\mathrm{Y}$ \\
\hline H9 & P29 & $\mathrm{F}$ & 4 & $\mathrm{~N}$ \\
\hline H9 & $\mathrm{P} 30$ & $\mathrm{~F}$ & 4 & $\mathrm{Y}$ \\
\hline $\mathrm{H} 10$ & P47 & $\mathrm{F}$ & 4 & $\mathrm{Y}$ \\
\hline $\mathrm{H} 10$ & P48 & F & 4 & Y \\
\hline $\mathrm{H} 10$ & P49 & $\mathrm{M}$ & 4 & $\mathrm{~N}$ \\
\hline $\mathrm{H} 10$ & P50 & $\mathrm{M}$ & 4 & $\mathrm{~N}$ \\
\hline H11 & P39 & $\mathrm{F}$ & 5 & $\mathrm{~N}$ \\
\hline H11 & $\mathrm{P} 40$ & $\mathrm{M}$ & 5 & $\mathrm{~N}$ \\
\hline H11 & P41 & $\mathrm{M}$ & 5 & $\mathrm{~N}$ \\
\hline H11 & P42 & $\mathrm{F}$ & 5 & Y \\
\hline H11 & $\mathrm{P} 1$ & $\mathrm{M}$ & 5 & $\mathrm{~N}$ \\
\hline $\mathrm{H} 12$ & $\mathrm{P} 3$ & $\mathrm{M}$ & 3 & $\mathrm{~N}$ \\
\hline $\mathrm{H} 12$ & P37 & $\mathrm{M}$ & 3 & $\mathrm{~N}$ \\
\hline H12 & P38 & $\mathrm{M}$ & 3 & $\mathrm{~N}$ \\
\hline
\end{tabular}



study group and the literature

\begin{tabular}{|l|c|c|c|}
\hline $\begin{array}{c}\text { Types of } \\
\text { Food }\end{array}$ & $\begin{array}{c}\text { Italian youths } \\
\text { (Mondéjar-Jiménez } \\
\text { et al., 2016) }\end{array}$ & $\begin{array}{c}\text { Spanish youths } \\
\text { (Mondéjar-Jiménez } \\
\text { et al., 2016) }\end{array}$ & $\begin{array}{c}\text { British } \\
\text { Students } \\
\text { in research }\end{array}$ \\
\hline Fruit & 41.90 & 37.82 & 28 \\
\hline Bread & 36.03 & 38.46 & Not identified \\
\hline Vegetables & 33.82 & 25.00 & 58 \\
\hline Pasta & 21.32 & 10.90 & 12 \\
\hline Eggs & 16.18 & 10.25 & 4 \\
\hline Yogurt & 5.15 & 7.69 & 4 \\
\hline Milk & 4.42 & 3.84 & 20 \\
\hline
\end{tabular}

\section{Table 5: Indicative comments from respondents highlighting influencing factors}

'Today's individuals do not mind wasting food, as it is so readily available and cheap, as I am the same. But if food was to become more expensive, then everyone would be encourage to waste less food, as they will not be able to afford to waste food' (P47).

'If food become more expensive, I would definitely start wasting less food' (P32).

'Why can't manufactures get rid of the 'best before' date and only have a reasonable 'Use By' date or if a product never goes off like pasta or rice, then have no date at all. It is almost like food manufacturers are trying to get consumers to waste huge amounts of food, as we are not all educated in food' (P40).

'If there was not the safety risk related to food product, I would definitely waste less food, but I am far too scared to risk it, so it is just easier to throw food away, rather than having food poisoning' (P14).

'......sometimes it is just easier to throw food away, than to keep it for another a meal, without worrying whether you have used it in time' (P27).

I would consider using the Olio app, but it does seem a bit time consuming and people today are time short, why would they want to waste time using the app. It is easier and more convenient to buy all your food from the supermarket, and what you do not want to just throw in the bin...' (47) 


\begin{tabular}{|c|c|c|c|}
\hline $\begin{array}{l}\text { First Initial } \\
\text { Coding }\end{array}$ & Secondary Coding & Third Coding & Fourth Coding \\
\hline Buying Habits & $\begin{array}{ll}\text { - } & \text { Shopping Lists. } \\
\text { - } & \text { Limited storage } \\
\text { space. } \\
\text { - } & \text { Special offers }\end{array}$ & $\begin{array}{l}\text { - Do follow shopping list. } \\
\text { Do not follow shopping } \\
\text { list. } \\
\text { - Write a shopping list in } \\
\text { accordance to size of shop. } \\
\text { - Special offers. }\end{array}$ & $\begin{array}{l}\text { - Cooking and shopping as a } \\
\text { household. } \\
\text { Cooking and shopping } \\
\text { individually. } \\
\text { - } \quad \text { Fail to follow a shopping list. } \\
\text { Buy foods on special offers } \\
\text { knowing they will not be } \\
\text { consumed. }\end{array}$ \\
\hline $\begin{array}{l}\text { Kitchen } \\
\text { Facilities }\end{array}$ & $\begin{array}{l}\text { - } \quad \text { Why waste food. } \\
\text { - } \text { Types of food } \\
\text { wasted. } \\
\text { - } \quad \text { Food packaging } \\
\text { - } \quad \text { Storage } \\
\text { Leftovers }\end{array}$ & $\begin{array}{l}\text { - Prepare, cook, and serve } \\
\text { too much. } \\
\text { - } \quad \text { Fruit, Vegetables, Milk. } \\
\text { Food packaging does not } \\
\text { extend shelf life of a } \\
\text { product. } \\
\text { - } \quad \text { Fancy vs leftovers. } \\
\text { - } \quad \text { Limited freezer space. }\end{array}$ & $\begin{array}{l}\text { - } \quad \text { Fancy Vs leftovers. } \\
\text { - } \quad \text { Limited storage - waste food. } \\
\text { Buy smaller packs of freezer } \\
\text { food. } \\
\text { - Spend more on weekly grocery } \\
\text { shops. }\end{array}$ \\
\hline $\begin{array}{c}\text { Student } \\
\text { awareness of } \\
\text { duration dates }\end{array}$ & $\begin{array}{ll}\text { - } & \text { Confusion. } \\
\text { - } & \text { No confusion. } \\
\text { - } & \text { Educated. } \\
\text { - } & \text { Food safety. }\end{array}$ & $\begin{array}{l}\text { Know what the 'use by' } \\
\text { stands for but not what the } \\
\text { 'best before' stands for. } \\
\text { - Follow duration dates } \\
\text { - Do not follow duration } \\
\text { dates. } \\
\text { - Food safety concerns } \\
\text { regarding meat but not } \\
\text { vegetables. }\end{array}$ & $\begin{array}{l}\text { - } \quad \text { Waste food on use by date. } \\
\text { - } \quad \text { Waste food on best before date. } \\
\text { - } \quad \text { Food poisoning. } \\
\text { - } \quad \text { Parental influence. }\end{array}$ \\
\hline $\begin{array}{c}\text { Student } \\
\text { awareness of } \\
\text { monetary value } \\
\text { of food waste }\end{array}$ & $\begin{array}{l}\text { - Yes, wasting } \\
\text { food waste } \\
\text { money. } \\
\text { No, wasting food } \\
\text { does not waste } \\
\text { money. }\end{array}$ & $\begin{array}{l}\text { - } \quad \text { Food cheap. } \\
\text { Money only wasted when } \\
\text { huge portions of foods are } \\
\text { wasted. } \\
\text { - Cannot visually see the } \\
\text { monetary value of food } \\
\text { waste. } \\
\text { Estimate weekly monetary } \\
\text { value of food waste. }\end{array}$ & $\begin{array}{l}\text { - Vegetables wasted, as perceived } \\
\text { cheap, but not meat, as seen as } \\
\text { the most expensive part of a } \\
\text { meal. } \\
\text { - Fail to comprehend the monetary } \\
\text { value of food waste adds up. }\end{array}$ \\
\hline $\begin{array}{l}\text { Student } \\
\text { awareness of } \\
\text { the } \\
\text { environmental } \\
\text { Impacts }\end{array}$ & $\begin{array}{ll}\text { - } & \text { Aware. } \\
\text { - } & \text { Not aware. } \\
\text { - } & \text { Educated. }\end{array}$ & $\begin{array}{ll}\text { - } & \text { Food packaging. } \\
\text { - } & \text { Methane. } \\
\text { - } & \text { Natural. } \\
\text { - } & \text { No idea. }\end{array}$ & $\bullet$ \\
\hline $\begin{array}{l}\text { Student } \\
\text { awareness of } \\
\text { the social } \\
\text { impacts }\end{array}$ & $\begin{array}{ll}\text { - } & \text { Aware. } \\
\text { - } & \text { Not aware. }\end{array}$ & $\begin{array}{ll}\text { - } & \text { Starving children. } \\
\text { - } & \text { Educated. } \\
\text { - } & \text { Future of food. }\end{array}$ & $\begin{array}{l}\text { - } \quad \text { Populations growing but not } \\
\text { enough food to feed everyone. } \\
\text { - } \quad \text { Over eating and under eating. } \\
\text { - } \quad \text { Seasonal. } \\
\text { - } \quad \text { Technology. }\end{array}$ \\
\hline $\begin{array}{l}\text { Primary } \\
\text { motivating } \\
\text { factors }\end{array}$ & $\begin{array}{ll}\text { - } & \text { Saving money. } \\
\text { - } & \text { Saving the } \\
\text { environment. }\end{array}$ & $\begin{array}{ll}\text { - } & \text { Saving money. } \\
\text { - } & \text { Too busy. } \\
\text { - } & \text { One duration dates. } \\
\text { - } & \text { Eood become expensive. } \\
& \text { value of food waste. } \\
\text { - } & \text { Improve safety of foods. }\end{array}$ & $\begin{array}{l}\text { Saving money primary } \\
\text { motivator. }\end{array}$ \\
\hline
\end{tabular}




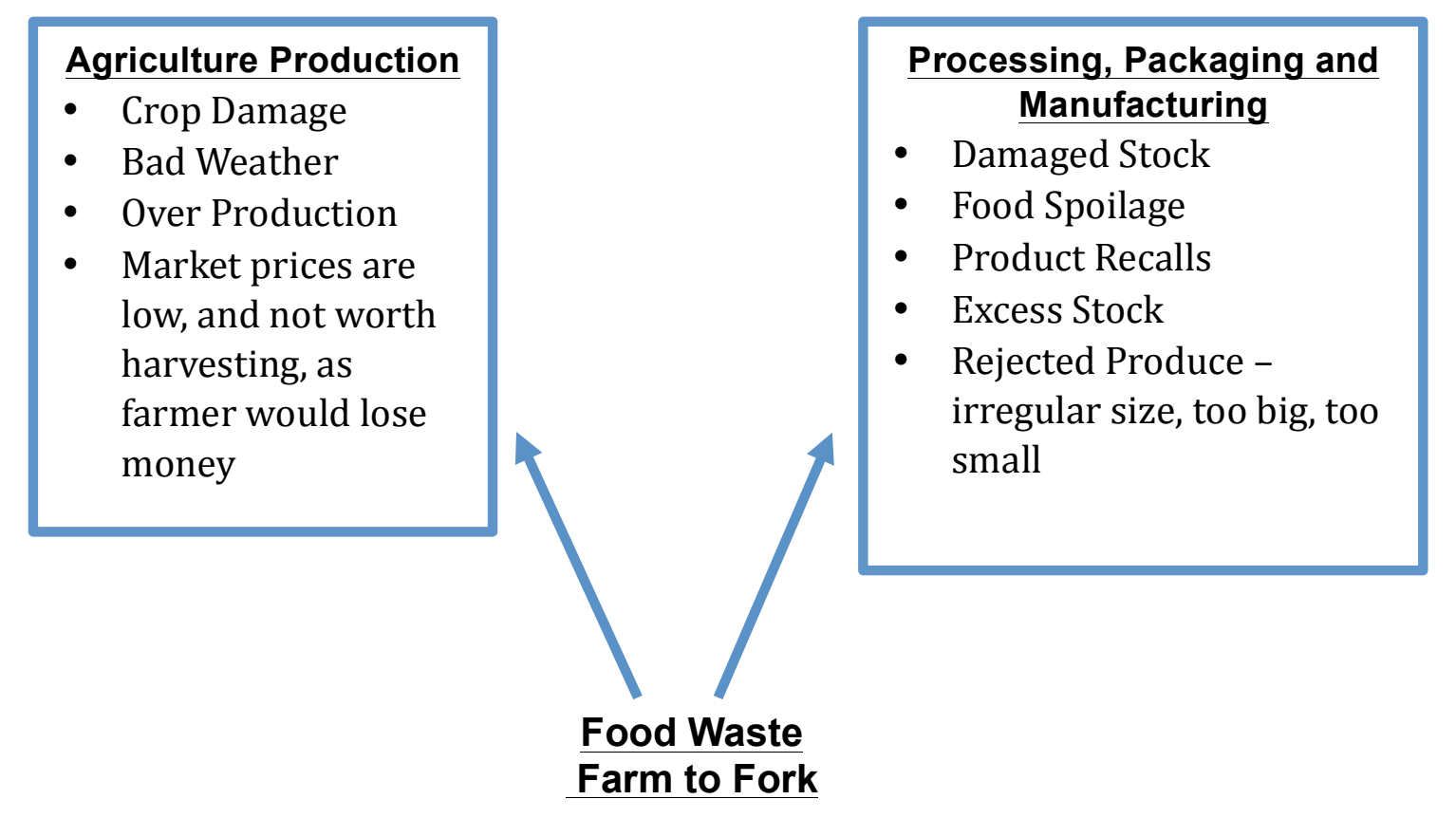

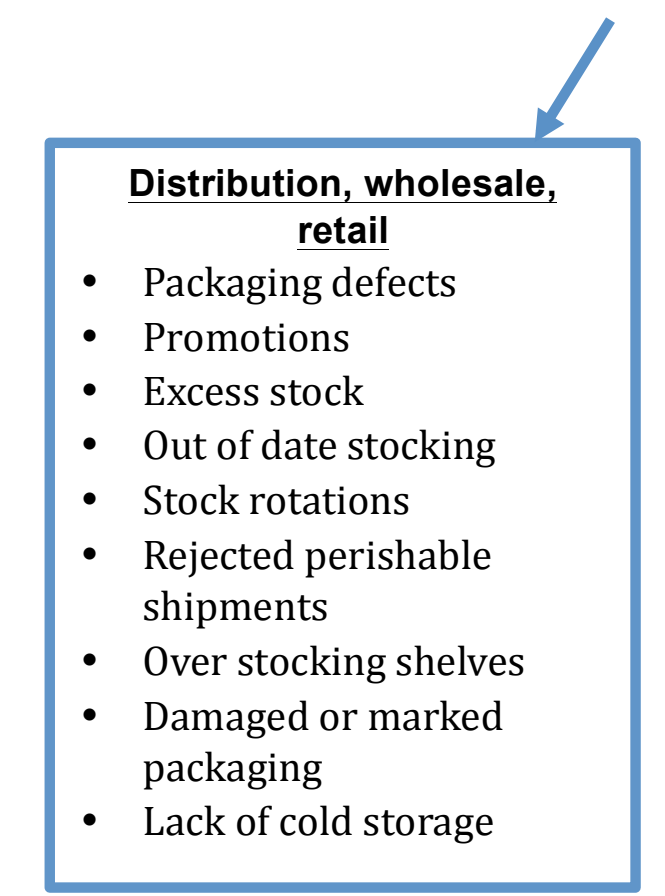

- Out of date stocking

- Stock rotations

Rejected perishable

Over stocking shelves

Damaged or marked

\section{Household}

- Lack of planning when shopping

- Preparing/ Cooking too much

- Impulse Purchases

- Lack of cooking skills

- Lack of storage knowledge

- Confusion between 'best before date' and 'use by date.'

- Buying too may perishable products

- Minimise Convenience

- Food safety

- Not eating what needs eating first

- Taste dissatisfaction

(Source: Adapted from Gunders, 2012)

Figure 1: Factors causing food waste from farm to fork 


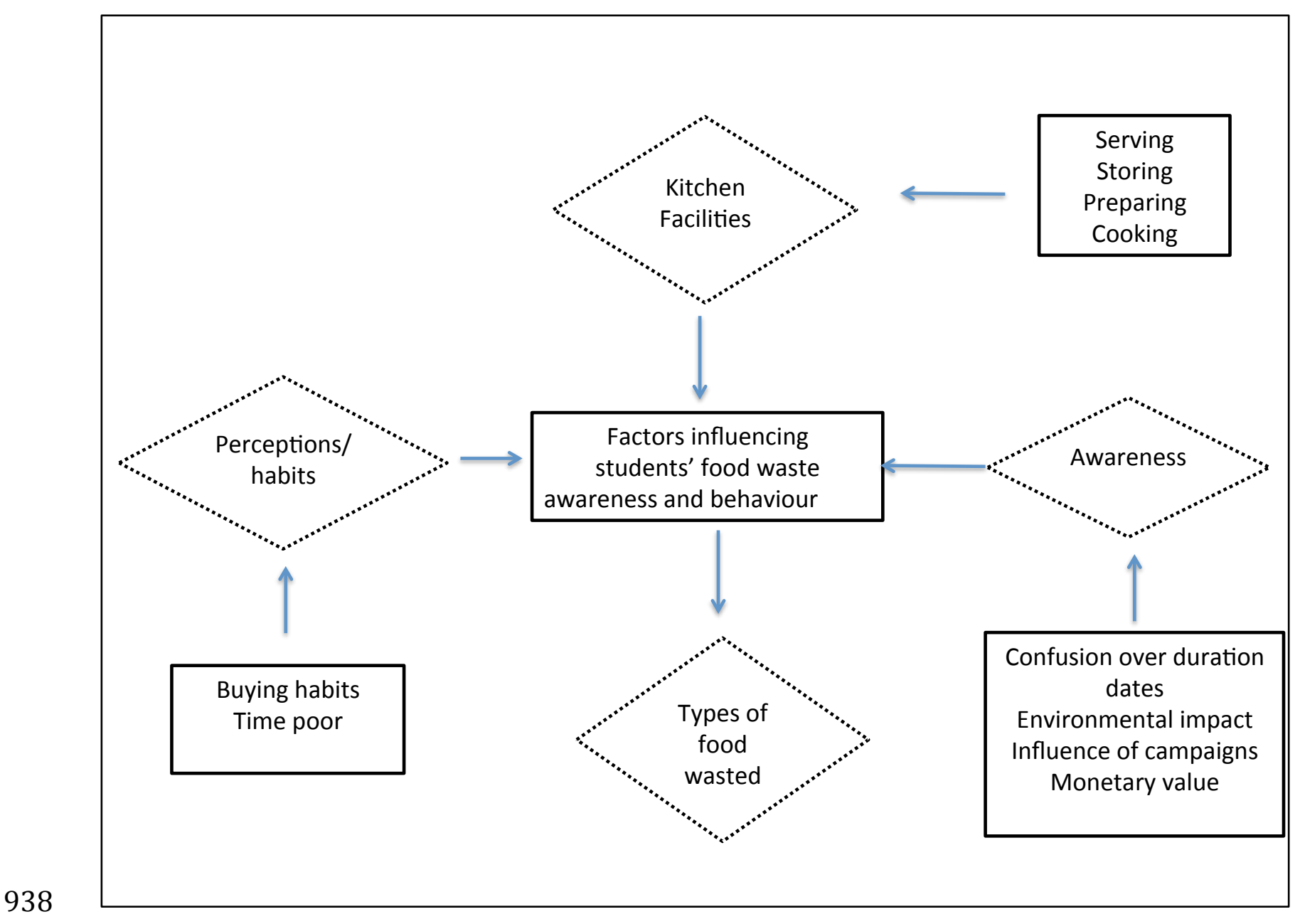

940 Figure 2: Factors identified in the literature said to influence students' food waste 941 awareness, and behaviour. (Adapted from Lyndhurst, 2007; Doron, 2013; Graham942 Rowe et al., 2014; Quested and Luzecka, 2014; Mondéjar-Jiménez et al., 2016; 943 Principato et al., 2015) 
